\title{
SHARING ECONOMY IN THE CZECH REPUBLIC: CASE OF PRAGUE*
}

\author{
Pavel Peterka ${ }^{1}$ \\ Radek Soběhart ${ }^{2}$
}

DOI: https://doi.org/10.31410/ERAZ.2019.185

\begin{abstract}
This paper analyzes the sector of the sharing economy in the Czech Republic using unique data from relevant sharing economy platforms. Potential increase in efficiency on markets using sharing economy platforms is demonstrated on transportation market in Prague using unique in terrain approach. First step towards more suitable legal framework is to clearly define the line between participants in sharing economy and regular entrepreneurs; set less restrictive rules for participants in sharing economy, deregulate the business environment and make compliance with legal system as simple as possible.
\end{abstract}

Keywords: Sharing Economy, regulation, bureaucracy, taxes.

\section{INTRODUCTION}

$\mathrm{G}^{\mathrm{s}}$ enerally valid and recognized definition of a sharing economy does not exist at the state level, let alone internationally. Experts around the world have yet to agree on how to define this phenomenon. For purposes of this paper definition of European Commission is used. European Commission described the functioning of the sharing economy in its study [1]. A valuable output of the study is the categorization of participants in the sharing economy into the intermediary body, provider and user.

As we have defined in [1], [2] the intermediate body is a key element of the current model of sharing economy. Intermediate body is he part of the chain of sharing mediates communication between supply and demand on the market. Intermediate body connects consumers on demand side on the market with providers on the supply side of the market. Intermediate body must have enough economic goods to share. Intermediate body also must provide a simple, clear and secure way of communication between the different users within the model and it must ensure that the contracts are adhered to and thus prevent fraudulent behavior. [1]

Lack of generally accepted definition causes problems. In practice, there are many situations where it is not clear whether sharing is involved or if the activity is just regular business activity. The logical question arises. Which rules set in the parallel business sector and to what extent must be respected within the sharing economy? Potential non-compliance with certain rules sets for traditional sectors at the sharing economy platforms may result in a serious threat to security and a disruption of the current framework of citizen protection - especially consumer and employee protection, tax collection and fair market conditions. Therefore, an optimal form of the legislative system is needed to enable the benefits of sharing services in and outside the transport sector to be maximized while minimizing possible negative impacts.

* The article was created as a part of the project "Smart City - Smart Region - Smart Community" (CZ.02. 1.01/0.0/0.0/17 048/007435).

1 Faculty of Social and Economic Studies, Jan Evangelista Purkyně University in Ústí nad Labem, Moskevská 54, Ústí nad Labem 400 96, Czech Republic

2 Faculty of Social and Economic Studies, Jan Evangelista Purkyně University in Ústí nad Labem, Moskevská 54, Ústí nad Labem 400 96, Czech Republic 


\section{BENEFITS, POSITIVES AND CHALLENGES OF THE SHARING ECONOMY ECOSYSTEM}

Theoretical background behind research of our scientific group further describes potential benefits, positives and challenges of the sharing economy ecosystem. [1], [2], [3], [4], [5] As main potential benefits and positives of sharing economy ecosystem were identified:

- Expansion of the supply of economic goods,

- Simplification of access to economic goods,

- Reduction of transaction costs and thus prices of economic goods,

- Extension of available options of increasing income,

- Participation of users in the ecosystem,

- Environment.

While as potential challenges of the sharing economy ecosystem were identified:

- Threat to equality of conditions on the market,

- Participants in sharing economy avoiding tax and other legal obligations,

- Breach of the existing framework for the protection of citizens (consumer and employee protection),

- Ensuring compliance of applicable legal standards and other rules by users of shared assets.

Abovementioned benefits, positives and challenges are connected to nature of sharing economy ecosystem which can be above all described as fast, new, flexible and efficient system in terms of connecting market participants together. The above-mentioned extension of the supply of economic goods and market access simplification reduces transaction costs for all market participants. In addition to that, sharing economy platforms increase the competitive pressures on the market, which, according to neoclassical economic theory, reduce prices. [6] More efficient use of already produced and often idle resources that sharing economy platforms allow reduces the need to produce brand new goods which has positive impact on the environment. [7]

\section{HIGHER EFFICIENCY IN PERSONAL TRANSPORTATION: CASE OF PRAGUE}

Sharing economy platforms in personal transportation in Prague is a very interesting regulatory laboratory. This chapter focuses on pragmatic side of sharing economy.

Prague is, unfortunately, an example rather negative. Therefore, the text seeks to capture the problematic situations associated with the operation of personal transport in Prague and on the basis of best practices from abroad, thus helping to set up a problem-free system that maximizes the possible benefits of sharing economy platforms operating in personal transport and minimizes any potential negative impacts.

Traffic in Prague is a living organism. Taxi transport and transport through sharing economy platforms have differences. Both types of personal transportation make a significant contribution to the sustainability of urban transport. Both groups fall into category door to door transport that can be used by people with special needs or specific preferences. Transport in this way greatly reduces the need to use own car for transportation to or in the city, thus limiting the need to park the car. Analyses [8], [9] show that sharing economy platform Uber is $30 \%$ more 
efficient than standard taxi in terms of occupancy and mileage and hundreds of percent more efficient than standard transportation system with single driver using car for commute.

The following documents must be obtained to be legally allowed to provide taxi services: ID of the taxi driver, trade license, trade license related to the registration at the financial office, the health insurance company and the Czech Social Security Administration, and a special concession. In addition to all that, the taxi car must be visibly identified and equipped with one of the officially accepted taximeters. Beyond these tasks, the applicant must complete the test from the topography of the capital city of Prague.

Table 1: Tasks necessary to become a taxi driver in Prague

\begin{tabular}{|l|c|c|}
\hline \multicolumn{1}{|c|}{ Task } & Time (h) & Fees (EUR) \\
\hline Initial study of the environment. & 5 & \\
\hline Phone calls with municipal authorities. & 2 & \\
\hline Taxi drivers license request and journey to the place of permanent residence. (2x) & 8 & 16 \\
\hline Photographs necessary for issuing a license taken elsewhere. & 1 & 5 \\
\hline Request for trade certificate and request for concession. 3 visits. & 4 & 40 \\
\hline Communication with financial office, social security office and health insurance office. & 3 & 5 \\
\hline Study time for topography test & 17 & \\
\hline
\end{tabular}

Obtaining these documents requires visiting a number of public offices. Some of those need to be visited personally and several times. It takes hours of time to transport, hours necessary for search for information, and standing in queues. Moreover, the waiting periods of the documents are interwoven. Passing through the process lasts about 5 months, and mandatory activities combined take about 40 hours. Fees combined climb up to 70 EUR. [9]

It is no surprise that the digital platform like Uber has attracted so much attention. In the year 2018, 2,000 drivers used the Uber application and its service in Prague was used by 300,000 people. [10] Simplicity of the application and connection to the process from both the customer's position and the driver's position has made the application a popular tool. Shared platforms have extended the offer of this type of transport to formerly unpopular locations which increased the availability of such service, making it easier for the transport system in Prague to meet customer needs.

This, of course, has raised a wave of protests and complaints from classic taxi drivers who feel cheated. Sharing economy platforms such as Uber, Liftago, Taxify and others provide similar service to the service provided by classic taxis. But taxi drivers must go through the aforementioned process, which carries a lot of costs. Taxi service is in the second paragraph of Act No. $111 / 1994$ Coll. defined as ,... passenger transport for customer needs which includes the carriage of persons, including their luggage, by vehicles intended for the carriage of not more than 9 persons, including the driver. Taxi service doesn't include a regular passenger service, an international shuttle service or occasional road passenger transport." Taxis are therefore a business activity, which creates a relationship between the operator and the transported person.

However, platform representatives claim that they are not a classic taxi and they position themselves rather as a contractual transport. On such a „contract” drivers, the law requires different obligations than on a regular taxi. One of the conditions, however, is the need to agree with the customer on the price before the actual journey. They are not allowed to take customers on 
the street like a classic taxi, they can't stand on a taxi stall or ride in lanes reserved for public transportation and taxi only. Sharing economy platforms in Prague mostly fit into this category. By moving on the edge of the law, this type of service gets into the gray zone, which is not optimal for legal certainty not only in the field of transport. The situation is discussed at courts in Prague, Brno, but also in London and elsewhere in the world.

Ministry of finance of the Czech Republic [11] sides with the opinion that sharing economy platforms such as Uber do provide taxi service, which means that they should follow all the rules and obligations set for standard taxi services.

However, it is clear on the example of Prague that this is an excessive regulation that doesn't really help. Hours of time, waiting months, yellow cars, taximeter, metering at a special location, and resulting service does not get higher quality. On the contrary. Taxi service in Prague had one of the worst reputations in the world.

Uber is much simpler. Drivers have to register at the platform and obtain a standard business license. Consumers choice is clear. Consumers familiar with the environment voluntarily chose sharing economy platforms with all mentioned benefits and threats over traditional taxis. Unnecessary regulation of sharing economy platforms may dismiss the positive effect of new business models that solve various legal problems.

\section{SUGGESTIONS}

Sharing economy helps the traditional economy, society and ecology. [1], [2], [3], [4], [5] The question is: How to set the rules so that the society really benefits from sharing economy with fair respect for both small and big businesses?

- Set a threshold that will divide participants in sharing economy into traditional entrepreneurs and participants who genuinely share. Set less restrictive rules for people that do not exceed set threshold;

- Participants in sharing economy that do not exceed certain revenue (e.g. three times minimal wage) shouldn't be required to fulfill all duties that standard businesses have. This will motivate participants to follow rules in simplified legislative framework as these rules will not be prohibitive (examples from transportation and short-term rentals described earlier in the text). Consumers should be notified and potential risks coming from buying goods or services from non-professionals should be explained.

- Clear definition of traditional entrepreneurs and those who genuinely share and enforce all rules;

- Clear definition of rules for individual subjects in sharing economy and enforcing them is necessary to achieve compliance with all the rules which will help to increase transparency in tax related issues and to maintain current level of consumer protection.

- Deregulation;

- Equal conditions on markets for all entrepreneurs should be reached by deregulation rather than adding more excessive regulation. If unequal conditions on market arising from laws or regulations that are only enforced on one group of market participants are identified, option of deregulation should be considered first.

- Simplification of legal system;

- Compliance with systems, legal or other, is significantly affected by difficulty of meeting set obligations. Simple systems with user friendly interface that allows meeting all 
obligations at one place generally achieve higher rate of compliance than complicated non digitalized systems. If there are necessary e.g. inspections that are reasonable in many cases, they should be done and paid for at once. This is not just the case of sharing economy but case of whole business environment in the Czech Republic.

\section{CONCLUSION}

This paper summarizes possible benefits and challenges that are accompanied with emergence of sharing economy platforms. Together with the positive effects of a sharing economy, it is necessary to face many challenges that the disruptive nature of sharing economy platforms create to society. Key challenges have been identified: maintaining standards of consumers protection and security, eliminating tax evasion and other legal obligations, and ensuring fair and equal business environment. Consumer protection may be jeopardized by non-compliance with standards of standard markets. However, this can also happen when dealing with traditional entrepreneurs. The same applies for the risk of tax evasion. [12] Ensuring equal and fair market conditions for all participants is the biggest challenge. An environment where two entrepreneurs run an identical service, but only one of them complies with the applicable laws that are accompanied with costs is not a sign of equal and fair business environment. This situation must not occur on a fair and efficient market.

Some obligations and regulations in personal transportation and short-term rentals are excessive and ineffective. Two described cases (transportation and short-term rentals in Prague) show that sharing economy helps identify excessive regulation and offers more efficient way of achieving goals that current legislative system was designed to solve.

Text of the paper offers 4 suggestions on how to get rid of excessive regulations. These suggestions include: clear definition of those who are regular entrepreneurs in sharing economy environment by setting a threshold that draws line between regular entrepreneurs and genuine participants in sharing, setting less prohibitive rules for those who do not exceed this limit, deregulation of business environment in the Czech Republic and simplification of processes necessary to meet obligations set by legal framework. Following these suggestions would improve situation regarding sharing economy in the Czech Republic by addressing the most pressing issues that are: tax evasion, consumer protection and implementation of positive aspects of sharing economy platforms into traditional economy and current legal framework.

\section{REFERENCES}

[1] Goudin, P. (2016). The cost of non-Europe in the sharing economy. [Online]. European Parliamentary Research Service. [8th of march] Available: http://www.europarl.europa.eu/ RegData/etudes/STUD/2016/558777/EPRS_STU(2016)558777_EN.pdf

[2] Peterka, P., Soběhart, R., Jílková, J. (2018) Sharing Economy - a Challenge of the 21st Century?, Littera Scripta 2018 (volume 11), České Budějovice, ISSN-1805-9112

[3] Kijučnikov, Krajčík, Vincůrová, (2018), International sharing economy: The case of Airb$\mathrm{nb}$ in the Czech Republic. Economics and Sociology 11(2), June 2018

[4] Florian, Teubner, Weinhardt. (2016). Trust in the sharing economy. Die Unternehmung, Pages 26 - 44, DU, Jahrgang 70 (2016), Heft 1, ISSN print: 0042-059X

[5] Chamber of Commerce of the Czech Republic, (2018). Doporučení pro rozvoj sdílené ekonomiky. [Online]. Chamber of Commerce of the Czech Republic. [8th of march]. 
Available https://www.komora.cz/tiskova_zprava/hospodarska-komora-predstavila-50-doporuceni-rozvoj-sdilene-ekonomiky-ceske-republice/

[6] Cowen, Tyler; Tabarrok, Alex (2013). Modern Principles: Microeconomics (2nd ed.). New York: Worth Publishers. pp. 228-29. ISBN 978-1-4292-3999-8.

[7] Möhlmann, M. (2015), Collaborative consumption: determinants of satisfaction and the likelihood of using a sharing economy option again. J. Consumer Behav., 14, 193-207. doi: 10.1002/cb.1512.

[8] Hall, J. V., \& Krueger, A. B. (2015). An Analysis of the Labor Market for Uber's Driver-Partners in the United States. ILR Review, 71(3), 705-732.

[9] CETA, (2017), Bariéry vstupu na trh taxislužby v Praze jsou obrovské, je nutné celý proces zjednodušit. [Online]. Centre for Economic and Market analyses. [8th of march]. Available: http://eceta.cz/tz-studie-bariery-vstupu-na-trh-taxisluzby-v-praze-jsou-obrovske-jenutne-cely-proces-zjednodusit/

[10] Uber, (2018), Internal data documents shared with authors collective.

[11] Ministry of Finance Czech Republic, (2017), Sdílená ekonomika: přehled opatření. [Online]. Ministry of Finance Czech Republic. [8th of march]. Available:https://www.mfcr.cz/ cs/aktualne/aktuality/2018/sdilena-ekonomika-prehled-opatreni-31496

[12] CETA, (2015), Studie: Stínová ekonomika v České republice. [Online]. Centre for Economic and Market analyses. [8th of march]. Available: http://eceta.cz/studie-stinova-ekonomika-v-ceske-republice/ 